\author{
Győrffy Alexandra \\ Eszterházy Károly Egyetem \\ gyorffy.alexandra@gmail.com
}

\title{
A NYELVI HUMOR SZEREPE A SPORT OKTATÁSÁBAN
}

\section{Bevezetés}

A humor a mindennapjaink szerves része, az életünk minden területén megjelenik. A humor képes felkelteni az érdeklődésünket egy téma iránt, gondolatébresztőként szolgál a tudatunk és lelkünk számára egyaránt, valamint kiváló motiváló tényezőként is alkalmazható. A mai világban a pedagógusok és az edzők a fent írtak miatt próbálják alkalmazni a tanórákon, illetve az edzéseken. Napjainkban a pedagógusoknak nagyon nehéz diákjaik érdeklődését felkelteni a tanulás, illetve a tanórai témák iránt. Hasonló a helyzet az edzők esetében is, hiszen a digitális eszközök elterjedésével a fiatalok inkább választják a technikai eszközök világát, mintsem azt, hogy sportoljanak valamit. Az edzőknek ezért nagy gondot jelent az, hogyan motiválják a gyerekeket a sport iránt. Tanulmányomban arra keresem a választ, hogy a nyelvhasználathoz kötődő humor alkalmazható-e, illetve amennyiben igen, akkor milyen formában alkalmazható a sportoktatásban. Továbbá azzal foglalkozom, hogy a verbális humor alkalmazhatóságát tekintve mutatkoznak-e különbségek az iskolai és iskolán kívüli oktatási folyamatban. Míg az iskolai keretek között zajló tanítási óra kötelező, addig egy edzés választott tevékenység. Mindkét színtér szabályozott struktúrájú, ám a sportfoglalkozást ennek ellenére kötetlenebbnek vélik, valószínűleg éppen azért, mert saját választáson alapul. Jelen kutatáshoz kérdőíves, valamint interjús felmérést is végeztem az egri sportszervezetekben sportolók és edzőik körében. Összehasonlítom, hogy a két eltérő kommunikációs színtéren (az iskolai tanórán, illetve a sportoktatásban) hogyan alkalmazható a humor, milyen negatív és pozitív következményekkel jár, járhat a humor használata. Ehhez az összevetéshez korábbi kutatási eredményeimet használom fel, mely során az egri állami középiskolák tanáraival készítettem kérdőíves vizsgálatot.

A bevezetést követően elsőként röviden ismertetem a nyelvészeti humor elméleti hátterét, majd összevetem a két kommunikációs színteret, megvizsgálom, milyen hasonlóságok és különbségek mutatkoznak az iskolai tanóra és a sportoktatás között. Ezután arra a kérdésre próbálok felelni, hogy lehet-e egyáltalán a pedagógus/edző humoros a foglalkozáson, vagyis mit gondolnak a kutatók, a közvélemény, ha a foglalkozást vezető személy jellemvonásai között szerepel a humorosság. Végül bemutatom a két kommunikációs területen végzett kutatásom eredményeit. 


\section{A nyelvi humor}

\subsection{Nyelvészeti humorkutatás}

A humor nyelvészeti kutatásának két problematikus eleme a verbális humor mibenléte és osztályozása. A humor a megszokottól eltérö, ellentéten alapuló jelenség, a humoros hatás a sémák megsértésének következménye. Ezt az értelmezést támasztja alá Fülöp Lajos véleménye is: „A nyelvi humor a felhasznált hangtani, helyesírási, nyelvtani és szókészlettani eszközökben, stilisztikai és verstani formákban, szerkesztési lehetőségekben és a nyelvi alapú viccekben megnyilvánuló nevetségesség” (Fülöp 2013: 60). A verbális humort többnyire a nyelvi szintek szerint kategorizálják, aminek problematikusságát Palágyi abban látja, hogy ha formailag nem találnak semmilyen megszokottól eltérőt, akkor más osztályozási kategóriákat vesznek figyelembe, ezzel elválasztják egymástól a szemantikát és a grammatikát, így félrevezető értelmezések születhetnek. A humoros helyzet ezeknek a kategóriáknak az összjátékából következik, tehát egy sokkal tágabb osztályozási rendszert követel meg, hogy a humort mérni lehessen (Palágyi 2016).

Az első fontosabb nyelvészeti humorelmélet a Victor Raskin nevéhez köthető szemantikus szkriptelmélet. Ezt Salvatore Attardo fejlesztette tovább és mutatta be 1994-ben, és arra keresi a választ, hogy „mi a humoros jelenség lényege; mik a szükséges és elégséges feltételei annak, hogy valamit "humorosnak«, azaz nevetést kiváltónak fogjunk fel” (Riszovannij 2008: 213). Az elmélet két részből áll, egyrészt egy hipotézisből, mely szerint egy szöveg akkor lesz vicces, ha két feltétel teljesül (vö. Riszovannij 2008):

- az adott szövegszegmens két különböző szkripttel kompatibilis, ezek átfedik egymást

- a két szkript ellentétes egymással, így oppozíció jön létre.

Az elmélet másik része a grice-i maximákat módosítja:

1. Annyi információt adj, amennyi a vicc számára szükséges!

2. Csak azt mondd, ami kompatibilis a vicc világával!

3. Csak azt mondd, ami releváns a vicc számára!

4. Meséld hatékonyan a viccet!

Az elmélet problematikus részét képezi, hogy nehezen illeszthető be egy kategóriába. Ugyan a humorelmélet nevet viseli, de nem lehet eldönteni, hogy a viccet, humort vagy a komikumot tárgyalja a hipotézis. Az elmélet két úton haladt tovább a kritika hatására, az egyik irányban a vicceken kívül más humoros szövegtípusokat is a vizsgálatuk alá vontak a kutatók, a másik úton pedig az elmélet bizonyos részeit változtatták meg (Riszovannij 2008: 213-219).

A nyelvészeti szempontú humorkutatás egy másik irányzata a szociolingvisztika felől közelít. Míg Raskin humorelmélete a viccekre korlátozódott, addig a szociolingvisztikai irányzatba beletartozik a humoros szituációk elemzése is. A kutatás tárgya a Helga Kothoff nevéhez köthető elméletben a viccelődés, a másik „ugratása”. Arra keresi a választ, hogy „miként határozzák meg a humoros kommunikáció céljai annak működését" (Riszovannij 2008: 217). 
Egy harmadik nyelvészeti megközelítésű humorkutatás Arisztotelész megállapításából indul ki, mely szerint valami hiba (ami fájdalmat okoz) eredménye a nevetés. Ezen a vonalon elindulva Thomas Veatch egy hármas skálát alkotott a humoros folyamat elemeiből. A folyamat két elemének, a normaszegés észlelésének és a normalitásnak egyensúlyban kell lennie, különben a hatás nem következik be, vagyis nem vált ki nevetést. Hiszen ha a szabálysértés észrevétlen marad, elmarad a nevetés, ugyanis nem veszik észre a normaszegést, így a hatás is elmarad, a másik esetben pedig, ha a túlzott normaszegés felé billen a mérleg, a folyamat következménye nem nevetést vált ki, hanem felháborodást, sértődöttséget (Riszovannij 2008: 213-19).

Összegezve a nyelvészeti kutatásokat elmondható, hogy a humor elkülöníthető a komikumtól. Komikumnak tekintik azt, ami nevetést vált ki, így az egyik útvonalon a komikus szövegek vizsgálatával foglalkoznak, míg a másik irányvonalon a nevetéskultúrára vonatkozó kérdések vizsgálata folyik.

A kérdés, hogy ezek a kutatások mennyire hozhatók összhangba egymással, vagy mennyire zárja ki egyik a másik eredményeit. A humor sokarcú jelenség: ha átfogó képet szeretnénk kapni, a kutatásnak interdiszciplinárisnak kell lennie.

\subsection{A humor megértése}

Bizonyos elképzelések szerint a humor és a viccek kognitív folyamatnak tekinthetőek. A kognitív kutatások az elmélet és a gyakorlat egyensúlyára törekednek, hiszen a gyakorlati tapasztalatok beépülnek az elméleti keretbe. A humort azért tekintik kognitív folyamatnak, mert a keletkezést és befogadást követően a humor megértéséhez mentális aktivizáció szükséges. Hidasi Judit tanulmányában megállapítja, hogy: „A verbális humor nem statikus, hanem dinamikus müfaj: valójában diszkurzív cselekvés, interaktív alkotás. A működése feltételezi nemcsak a produkciót, hanem a recepciót is" (Hidasi 2008). Az interaktív folyamat megértéséhez kognitív képességek szükségeltetnek (Palágyi 2016: 333).

Éppen ezért nem mindegy, hogy a humor milyen korosztályt céloz meg, ugyanis egyfajta kognitív érettség nélkülözhetetlen a humor megértéséhez. A kognitív humorelméletek terén sincsen egyetértés a humor definíciójával kapcsolatban, a kutatók csupán valamilyen ellentmondás meglétében értenek egyet, ám hogy ez az ellentét hogyan és miből fakad, arról megoszlanak a vélemények. Schultz szerint az elvárt és a kapott végszó közötti eltérés a humor forrása, Beathie elméletében a humor két össze nem illő dologból ered, Schoppenhauer meglátása szerint a vázolt és a valós helyzet közti különbség felismeréséből származik. Közös vonása az álláspontoknak, hogy bizonyos mentális érettség szükséges a humorértéshez, valamint kiemelik azt, hogy létjogosultsága van az órán, tehát a pedagógus, ha megfelelően alkalmazza azt, akkor a saját dolga megkönnyítése mellett a képességeiket, kritikus gondolkozás kialakítását is fejlesztheti a gyerekeknél. 


\section{Két eltérő kommunikációs színtér összevetése}

Korábbi tanulmányaimban kifejezetten a tanórához szorosan kapcsolódó humort vizsgáltam, mely során az került középpontba, hogy a pedagógusoknak nehéz a diákok érdeklődését felkelteni a tanóra, a tantárgy, a téma iránt, illetve motiválni őket a tanulásra. A kutatásaim során kezdett el érdekelni, hogy vajon egy másik kommunikációs színtéren, az edzésen (amely számos hasonlóságot és különbséget is mutat a tanórával összehasonlítva) mennyire tartják alkalmazhatónak az edzők a humort. Az első alapvető különbség a tanítási óra és a sportfoglalkozás között, hogy míg a tanóra kötelező cselekvés, addig az edzés szabadon választható tevékenység. A gyerekek kötelesek iskolába járni, a tankötelezettségük egészen a 16 éves korukig tart, ezzel ellentétben az edzés egy fakultatív foglalkozás, amiért sok esetben még fizetni is kell. Az edzés szabadon választott szabadidős elfoglaltság, minden fiatalnak az önálló akaratából történik. Így az iskolában a diák nem tudja megválasztani azt, hogy mit szeretne tanulni, előre felépített tanterv szerint meg van határozva, milyen tantárgyakat kell tanulnia, míg a sport teljes mértékben önálló választás, hiszen egyrészt azt is kiválasztja a gyermek, hogy szeretne-e sportolni, másrészt azt is eldöntheti, hogy milyen típusú sporttevékenységet üz. Ebből kiindulva azt gondolom, a sportfoglalkozáson az edzőre könnyebb feladat hárul, hiszen csupa olyan gyerekekkel kell együtt dolgoznia, akik önszántukból választották az ő edzését, feltételezhető, hogy kevésbé kell motiválni őket a mozgásra, mint a tanítási órán jelenlevő diákokat. Mindkét kommunikációs helyszínre jellemző, hogy a karmesteri szerep a foglalkozást vezető tanár vagy az edző kezében van. Ö irányítja az oktatás teljes menetét, tehát a foglalkozáson jelenlevő nyelvi humor is nagyban a pedagógustól, edzőtől függ. Az edzés szabad választásából adódóan a sportfoglalkozás légköre kötetlenebb, szabadabb munka jellemző rá, mint egy iskolai órára, ahol kötött, feszes munka jellemző az oktatásra. A két kommunikációs terep felépítését tekintve azonos, hiszen a hagyományos óratervezet az RJR-modell alapján strukturálódik, amely 3 egységre osztja a tanítási órát. Az órát a pedagógus a ráhangolással indítja, melyben felmerülhetnek kérdések az adott órai anyaggal kapcsolatban, az előzetes tudás mozgósítása zajlik. Ezután a fö részben a jelentésteremtés során az anyag befogadása, a régi és új horizontok összeolvadása történik. Végül a reflektálás fázisával zárja a tanár a tanítási folyamatot, ahol a reagálás az új ismeretekre és a hiányosságok pótlásával zárul a tanóra. Ez a hármas egység jelenik meg az edzés strukturálódása folyamán is. E hármas egység a bemelegítés, a fö rész, és a nyújtás elemekre osztható. A bemelegítés során nemcsak a gyerekek izmait készíti fel az edző az edzésmunkára, hanem az agyukat, vagyis a gondolkodásukat is ráhangolja a sportfoglalkozásra. Ahogy az RJR-modell ráhangoló egységében is az adott óra témájához kapcsolódó feladat jelenik meg, úgy az edzés bemelegíto részében is olyan fóként játékos gyakorlatot alkalmaznak az edzők, amely kapcsolódik az edzés fó részéhez. Az edzés fó része teljes mértékben párhuzamba állítható a hagyományos óratervezet jelentésteremtés egységével, hiszen az aktuális edzés „tananyaga” jelenik meg az edzés középső részében. A harmadik blokk pedig az edzés lezáró szakasza, a nyújtás, 
mely során a bemelegítéshez hasonlóan nem csupán az izmok lazítása történik, hanem az edzés fö részén felmerült problémák, kérdések megvitatása is zajlik. Ez történik meg az RJR-modell reflektáló szakaszában is, bár itt kissé kötöttebb formában történik a reagálás az ismeretekre, míg az edzés végén a lezáró szakasz szabadabb, kötetlen beszélgetős, információcsere zajlik.

Összehasonlítva a két kommunikációs színteret elmondható, hogy felépítését és a foglalkozásvezetést tekintve azonosságok fedezhetőek fel, ám a kötöttség, szabad választás miatt az oktatás eltérő hangulatú légkörben történik, így különösen érdekes e két helyszínen megvizsgálni azt, hogyan fér bele a humor a foglalkozások keretei közé, hogyan vélekednek a pedagógusok, illetve a sportolók a humor alkalmazhatóságáról a tevékenységek során.

\section{Lehet-e humoros a pedagógus/edző?}

Mielőtt a kutatási eredményeket ismertetném, melyben a pedagógusok és a sportolók véleménye jelenik meg a humor alkalmazhatóságáról a foglalkozásokon, érdekesnek tartom megvizsgálni azt, hogy a szakirodalom, a kutatók hogyan vélekednek arról, ha egy pedagógus vagy egy edző humorizál a tanórán vagy az edzésen. A tanításról alkotott hagyományos elképzelésekben nem szenteltek figyelmet a humor szerepének, ma már egyre többen érvelnek amellett, hogy a humor alkalmazása befogadhatóbbá teszi a tananyagot (Pap 2006; Séra 2008; Schirm 2013). Nikitscher Péter (2016) azonos véleményen van Milyen a jó pedagógus? címủ tanulmányában ugyanis „az utca emberével” készített felmérést, melyben a válaszadóknak arra a kérdésre kellett felelni, hogy mi kell ahhoz, hogy valaki jó pedagógus legyen. A megkérdezettek 78\%-a a fontos vagy nagyon fontos kategóriába sorolta azt, hogy a tanárnak legyen humorérzéke. Tehát a közvélemény szerint egy jó pedagógus rendelkezik humorérzékkel. De vajon megjelenik-e ugyanúgy az edző jellemvonásai között a humorérzék a kutatók szerint? Harasztiné Sárosi Ilona (2014) az edző és sportoló kommunikációját kutatva kiemelte az edző mint vezető pozitív és negatív jellemvonásait. A humor egyértelműen helyet kap az edző pozitív vezetői tulajdonságai között. A kutatók és a közvélemény álláspontját megvizsgálva elmondható, hogy a tanárok és edzők pozitív tulajdonságai közé sorolják azt, ha humorosak a foglalkozásokat vezetők. A humornak tehát helye van a tanórán, illetve az edzések során, bizonyos helyzetekben kiváló megoldásként szolgál, ha ezt alkalmazza a pedagógus.

\section{Két eltérő kommunikációs színtér kutatási eredményeinek összehasonlítása}

Kiinduló hipotézisem, hogy a tanítási óra és a sportfoglalkozás eltérő kommunikációs színtér, ezért kérdőíves kutatást végeztem arra vonatkozólag, hogy miképpen látják a két kommunikációs helyszín főszereplői a humor alkalmazását a tanítási órán és 
a sportfoglalkozáson. Véleményem szerint a humor mindkét területen alkalmazható lehet, ám más pozitív hatásai lehetnek, és eltérő veszélyekkel járhat a tanítási órán és az edzésen.

\subsection{A kutatások tárgya}

A kutatás során arra keresem a választ, hogy milyen hasonlóságok és eltérések mutatkoznak eltérő kommunikációs színtereken a nyelvi humor alkalmazhatóságával kapcsolatosan. Az egyik kommunikációs színtér a tanítási óra volt, így ehhez a kommunikációs helyszín vizsgálatához a kutatást gimnáziumi tanárokkal végeztem. A kutatómunkám során az Egerben található állami és egyházi középiskolákban végeztem kérdőíves kutatást, melyben arra kerestem a választ, hogy a gyakorló pedagógusok a tanítás újabb kihívásaira megoldásnak látják-e a humort. Összesen 9 iskola, gimnáziumok és szakközépiskolák 251 tanárával töltettem ki feleletválasztós kérdőívemet, mely így a reprezentativitás hiányának ellenére számos fontos adalékkal szolgálhat a pedagógiai gyakorlatról. A másik kommunikációs színtér vizsgálatához a kérdőíves kutatásomat az Eszterházy Károly Egyetem Sport Club női kézilabdázói között végeztem felnőtt és junior korosztályban.

\subsection{Kutatási eredmények összehasonlítása}

A kérdőív első kérdése során arra voltam kíváncsi, hogy a tanárok és a sportolók helyénvalónak tartják-e a humor megjelenését a foglalkozásokon. A 251 kitöltőből 238 tanár, azaz a megkérdezettek meghatározó többsége mondta azt, hogy a humor alkalmas ezeknek a problémáknak a leküzdésére. A sportolóknál ennél még egyértelműbb pozitív válasz érkezett a humor megjelenéséről, ugyanis a megkérdezett sportolók 100\%-a azt válaszolta, hogy a humornak helye van az edzések során. Ezután a már korábban ismertetett foglalkozások hármas egységében kerestem a humor alkalmazhatóságát, vagyis a foglalkozás mely szakaszában tudják elképzelni a pedagógusok, illetve a versenyzők a humort. A pedagógusok az RJR-modell hármas felépítését tekintve az óra elején tudják elképzelni, hiszen a humor segítségével a témára irányítják a diákok figyelmét, $s$ ezzel motiválják őket a tanulásra. Az adatközlők 58\%-a szerint a tanítási folyamat motiválás részében hasznosítható leginkább a humor. A sportolók ettől eltérő módon válaszoltak, hiszen ők elsősorban a levezetés szakaszában tudják elképzelni a humort, tehát úgy gondolják, hogy a munka elvégzése után kapjon szerepet az edző humorizálása. A pedagógusoknál a 3 terület esetén sokkal nagyobb különbségek mutatkoznak, hiszen véleményük szerint a humor helye az oktatási folyamat részein a következőképp alakul: motiválás $58 \%$, jelentésteremtés $14 \%$ és reflektálás $28 \%$. Ezzel ellentétben a sportolók szerint az előkészítő és befejező szakasz között csupán néhány voksnyi különbség mutatkozik: bemelegítés 45\%, fö rész 6\% és levezetés 49\%. Abban mindkét kutatást kitöltői egyetértenek, hogy a humornak vagy az oktatás elején vagy a végén kell szerepelnie, semmiképp se alkalmazza a vezető az oktatási folyamat fö részében. A humor használatát 
tekintve felmerülhet a kérdés, hogy kin vagy min múlik, hogy jelen van-e a humor a foglalkozáson. A pedagógusok úgy vélik, hogy a tanár személyiségétól függ, 221-en karikázták be ezt a választ. Ám a sportolók véleménye eltér a pedagógusok álláspontjától, hiszen szerintük az edzésen bizonyos szituációk hatására kerül be a humor a foglalkozásba. Meglátásom szerint ahhoz, hogy az adott helyzetből humoros megnyilvánulások szülessenek, az edző személyiségének alapvetően tartalmaznia kell a humorosságot, és a képességet arra, hogy a szituáció során képes legyen spontán humorosan reagálni, ezzel becsempészve a humort az oktatási folyamatba.

A kutatások utolsó részében arra a két kérdésre kerestem a választ, hogy milyen pozitív és negatív következményekkel járhat az adatközlők véleménye szerint a humor alkalmazása az oktatási folyamatokban. A pedagógusok állásfoglalása szerint a pozitív hatásokat tekintve, az oldott légkör megteremtése kapta a legtöbb voksot. A humor alkalmas arra, hogy előkészítse a tanuláshoz kedvező hangulati feltételeket, hiszen egy feszült atmoszférájú osztályban sokkal nehezebb tanítani, a diákok is feszélyezve érezhetik magukat, akkor pedig nem kapcsolódnak be az óra menetébe, passzívak maradnak. Az adatközlők szerint a humor második legnagyobb előnye a stressz és vizsgaszorongás csökkentésében mutatkozik meg, ugyanis a tanárok úgy vélik, hogy segítő hatással van a stresszes szituációban az, ha humorizálnak. Csupán pár szavazattal maradt le a tanulás élvezetesebbé tétele, a tanár-diák kapcsolat javítása és a figyelem felkeltése. A sportolók véleménye jelentősen eltér a pedagógusok véleményétől, ugyanis az atléták csupán a 7. helyre rangsorolták az oldott légkör teremtését a humor használatának pozitívumai között. A kézilabdázók szerint az edzésen alkalmazott humornak legnagyobb szerepe abban van, hogy élvezetesebbé tegye a sportfoglalkozást, illetve csökkentse a stresszt vagy szorongást. Egy edzés során számtalanszor előfordul olyan eset, hogy a sportoló nem képes bizonyos mozgásformákat egyből elsajátítani, többszöri gyakorlás szükséges ahhoz, hogy ezeket a mozgáselemeket sikeresen végrehajtsa, végül megtanulja. A rendszeres gyakorlás során előfordul, hogy kudarcot érez a sportoló, és a sok sikertelenség miatt stresszhelyzetbe kerül, amikor újra és újra elölről kell begyakorolni a mozdulatot. Az edző képes lehet ezt a sikertelenség okozta szorongást enyhíteni az általa alkalmazott humorral.

Ám a számos kedvező hatása mellett a humornak lehetnek negatív következményei is. A legnagyobb hátrányát abban látják a tanárok a humor tanórai alkalmazásának, hogy félreértésekhez és fegyelmezetlenséghez vezet, vagyis kiszalad az irányítás a pedagógus kezéből, és nem lehet a tanulók figyelmét visszairányítani a tananyagra, hanem poénkodás fogja uralni az egész órát. A másik dolog, ami miatt veszélyesnek tartják az oktatók a humor alkalmazását, hogy általa félreértések alakulnak ki az osztályban vagy a tanár-diák között. Ez előfordulhat, ám ha humorizál a pedagógus a diákok humorértését is fejleszti, azt pedig a tanárnak kell éreznie, hogy mi az a humor, ami használható az osztályban vagy diákkal szemben. Több olyan megjegyzés is érkezett a kitöltőktől mely szerint a humor megfelelő mértékủ használatának nincs semmilyen veszélye, vagyis ha a tanár az optimális mennyiségben és minőségben veszi igénybe, akkor nem lesznek 
negatív következményei. A sportolók merőben más véleményen vannak a humor veszélyeit tekintve az edzésen. Az ő meglátásuk szerint a legnagyobb hátránya az edzésen alkalmazott humornak, hogy eltereli a figyelmet a munkáról. Ez összhangban áll azzal a nézettel, hogy a sportolók merőben elutasították azt, hogy a sportfoglalkozás fö részében humorizáljon az edző.

Összességében elmondható, hogy a két kommunikációs színtéren tett kutatásból kiderül, hogy mindkét felmérés adatközlői szerint a humornak helye van az oktatási folyamat során, és mindkét kommunikációs helyszín szereplői szerint semmiképp se a foglalkozás fó részében kapjon helyet, hanem a motiválás és lazítás alkalmával használja a humort a vezető. Abban viszont már eltérés mutatkozik, hogy a pedagógusok szerint kétségkívül a tanár személyiségétől függ a humor használata, míg a sportolók szerint az edzésen adódó szituáció eredménye az edző humorizálása. A pozitív és negatív hatásokat nézve is eltérés jelenik meg, hiszen a tanárok az oldott légkör teremtésében, a kézilabdázók pedig a sportfoglalkozás élvezetesebbé tételében látják a humor legnagyobb előnyét. A hátrányokat tekintve a pedagógusok a félreértések kialakulásától és a fegyelmezetlenségtől tartanak a legjobban, a sportolók pedig azt nehezményezik, hogy a humor hatására elterelődik a figyelem a munkáról és ez hátráltatja az edzés folyamatát.

\section{6. Összegzés}

A tanulmányomban azt tártam fel, hogy két eltérő kommunikációs színtér résztvevői hogyan vélekednek a humor alkalmazhatóságáról a foglalkozásokon. Ahogy a humor a mindennapok szerves része, úgy a tanítási órán, illetve a sportfoglalkozáson is kiválóan alkalmazható eszköz. A tanórát és edzést összehasonlítva viszont elmondható, hogy más előnyeit lehet kamatoztatni a humornak, illetve más negatív következményekkel kell számolni a más-más kommunikációs helyszínen. Jelen tanulmány következő kutatásom alapját képezi, ugyanis a jövőben azt fogom vizsgálat alá venni, hogy a sportoktatás különböző sportágaiban, korosztályaiban, illetve az eltérő osztályok között mutatkozik-e eltérés a humor használatával kapcsolatosan.

\section{Irodalom}

Fülöp Lajos 2013. A nyelvi humorról. Erdélyi Toll 4: 60-68.

Harasztiné Sárosi Ilona 2014. Edző-sportoló kommunikációja, különös tekintettel a versenyidőszakra. Előadás 2014. április 16-án. http://mstt.hu/Konferencia_anyagok/ 2014/Alkalmazott_sportpszichologia/Harasztine_Sarosi_Ilona_-_Edzo-sportolo_ kommunikacioja.pdf (2019. 02. 12.)

Hidasi Judit 2008. Miért nem nevetnek vicceinken a japánok? In: Daczi Margit - T. Litovkina Anna - Barta Péter (szerk.): Ezerarcú humor. Segédkönyvek a nyelvészet tanulmányozásához 79. Budapest: Tinta Könyvkiadó. 51-62. 
Nikitscher Péter 2015. Milyen a jó pedagógus? - Elvárások, szerepek, kompetenciák az empirikus kutatások tükrében. Educatio 24/1: 129-139.

Palágyi László 2016. A verbális humor kognitív nyelvészeti megközelítése. Magyar Nyelvör 140/3: 332-346.

Pap János 2006. Humor az iskolában. Új Pedagógiai Szemle 56: 25-34.

Riszovannij Mihály 2008. Irányzatok és kihívások a nyelvészeti humorkutatásban. In: Daczi Margit - T. Litovkina Anna - Barta Péter (szerk.): Ezerarcú humor. Segédkönyvek a nyelvészet tanulmányozásához 79. Budapest: Tinta Könyvkiadó. 213-219.

Schrim Anita 2013. A humor szerepe a nyelvészet oktatásában In: Vargha Katalin - T. Litovkina Anna - Barta Zsuzsanna (szerk.): Sokszinü humor. Segédkönyvek a nyelvészet tanulmányozásához 151. Budapest: Tinta Könyvkiadó. 50-60.

Séra László 2008. Humor a tanulásban In: Daczi Margit - T. Litovkina Anna - Barta Péter (szerk.): Ezerarcú humor. Segédkönyvek a nyelvészet tanulmányozásához 79. Budapest: Tinta Könyvkiadó. 264-273. 